Jolanta Barbara Jabłonkowska

https://orcid.org/0000-0002-9121-4172

Akademia Wychowania Fizycznego we Wrocławiu

Wydział Wychowania Fizycznego i Sportu

jolenda@poczta.onet.pl

Bogusław Stankiewicz

https://orcid.org/0000-0003-0191-2813

Akademia im. Jakuba z Paradyża w Gorzowie Wielkopolskim

Wydział Turystyki i Nauk o Zdrowiu

bstankiewicz@zut.edu.pl

\title{
BACKPACKERZY Z POKOLENIA MILENIALSÓW O RYZYKU ZWIAZZANYM Z PODRÓŻOWANIEM: UJĘCIE TYPOLOGICZNE
}

\begin{abstract}
Abstrakt: Na potrzeby niniejszego artykułu analizie poznawczej poddano kategoryzację ryzyka wpisanego w doświadczenia podróżnicze backpackerów z pokolenia milenialsów. Podjęto także próbę jego usystematyzowania na bazie poznawczych, a także emocjonalnych wyróżników przedstawionych przez respondentów. Badania przeprowadzono w latach 2018-2020. W celu pozyskania respondentów posłużono się nielosowym doborem próby, zwanym metodą kuli śnieżnej (ang. snowball sampling). Badaniami objęto 409 backpackerów z pokolenia polskich milenialsów. Przeprowadzono z nimi pogłębione wywiady online, z których następnie wyodrębniono klucze kodowe, przypisano je bardziej znaczącym kategoriom oraz dookreślono zakresy tematyczne. Analiza zebranego materiału jakościowego posłużyła do podjęcia próby typologii ryzyka związanego z backpackingiem milenialsów i pozwoliła na wyodrębnienie pięciu jego zakodowanych kategorii. Pierwsza zawiera się w backpackerskiej postawie wobec podróży. Druga wpisana jest w poszukiwanie autonomii i niezależności. Trzecia (kalkulacja selektywna) wynika z zachowań adaptacyjnych, związanych z rachunkiem zysków i strat. Czwarta kategoria jest powiązana z potrzebami emocjonalnymi backpackerów i poszukiwaniem wrażeń. Z kolei ostatnia wiąże ryzyko z warunkami środowiskowymi oraz cechami kulturowymi obszaru recepcyjnego. Usystematyzowanie typologiczne ryzyka w backpackingu pozwala zrozumieć potrzeby tej grupy osób podróżujących i dostosować świadczone usługi do wymagań konkretnego pokolenia.
\end{abstract}

Słowa kluczowe: backpacking, ryzyko, milenialsi.

\section{WSTĘP}

W literaturze naukowej dominuje przekonanie, że ryzyko - obok przygody - jest jedną z najistotniejszych cech podróży backpackerskich (Fuchs, 2013; Patyra, Dłużewska, 2015; Wantono, Mckercher, 2020). Motywy takich działań są różnorodne. Dla niektórych stają się one sposobem na wykreowanie własnej tożsamości (Elsrud, 2001). Relacje z podróży, pełne brawurowych wyczynów, pozwalają bowiem backpackerom na zaprezentowanie się $\mathrm{w}$ aurze wyjątkowości i niezłomności. Ryzyko może też być wpisane w kierunek podróży, szczególnie gdy jej cel stanowią obszary powszechnie uważane za niebezpieczne. Podejmowanie takich wypraw jest zatem przymiotem jednostek o silnym charakterze. Zdaniem Leggata i Shawa (2003) ten ostatni wariant wydaje się najpełniej korelować $\mathrm{z}$ backpackingiem, gdyż ponoszenie ryzyka i stawianie czoła zagrożeniom w trakcie podróży to codzienność backpackerów.

Literatura przedmiotu pełna jest analiz dotyczących ryzyka w backpackingu (Desforges, 2000; Falconer, 2011; Lupton, Tulloch, 2002). Przeprowadzono badania dotyczące stosunku backpackerów do ryzyka (m.in. Jabłonkowska, 2015; Leggat, Shaw, 2003) i ich zaangażowania w ryzykowne działania oraz opisano tego przyczyny (m.in. Elsrud, 2001; Fuchs, 2013; Kozak, Crotts, Law, 2007; Lepp, Gibson, 2008; Reichel, Fuchs, Uriely, 2007; Ryan, 2003). Badacze zwrócili również uwagę na problemy zdrowotne backpackerów, wynikające 
z podejmowania działań ryzykownych (m.in. Piyaphanee i in., 2009; Potasman, Beny, Seligmann, 2000), oraz psychiczne, przede wszystkim związane z uzależnieniami (Bellis, Hughes, Dillon, Copeland, Gates, 2007; Fischer i in., 2010; Jabłonkowska, 2017b).

W niniejszym artykule badania nad tym zagadnieniem uzupełniono o dwa dodatkowe wątki. Pierwszy z nich to kategoryzacja ryzyka, rozpatrywana, by określić charakter działań podejmowanych przez backpackerów z pokolenia milenialsów oraz uporządkować i usystematyzować doświadczenia, uznane przez respondentów za ryzykowne. Działania te mają na celu poznanie tego szczególnego elementu ich funkcjonowania w podróży. Drugim wątkiem stała się próba usystematyzowania rodzajów ryzyka, ujęcia go w ramy typologiczne oparte na poznawczych i emocjonalnych aspektach jego oceny.

\section{MILENIALSI W TURYSTYCE}

Do grupy badawczej wybrano backpackerów z pokolenia milenialsów, czyli osób urodzonych w ostatnich dwóch dekadach XX w. (Baran, Kłos, 2014; Fazlagić, 2008), określanych także jako generacja $Y$, generacja MTV, cyfrowe dzieci wolnego rynku, pokolenie klapek i iPadów (Kubacka-Jasiecka, Passowicz, 2014) czy generacja Why (Kotler, Wong, Saunders, Armstrong,
2005; Tapscott, 2010). Pomimo ograniczeń finansowych i czasowych jest to społeczność o znaczącym potencjale aktywności turystycznej (Santos, Veiga, Águas, 2016). Przedstawiciele pokolenia Y mają duże doświadczenie w podróżowaniu, ponieważ od najmłodszych lat wyjeżdżają w różne miejsca jako turyści. Wielu z nich rezygnuje z turystyki masowej i szuka różnych form wypraw niezależnych, m.in. backpackerskich. Milenialsi w podróżach poszukują możliwości osobistego rozwoju, autentycznych doświadczeń, chcą „zanurzyć się" w lokalnych kulturach i obcych przestrzeniach (Kowalczyk-Anioł, 2012). Wymagają działań, rezultatów, szybkiej reakcji i gwarantowanej satysfakcji. Biegle i w sposób nieograniczony korzystają z Internetu. Mają wpływ na zmiany, które zachodzą na rynku turystycznym (Iyer, Reisenwitz, 2009; Pendergast, 2010).

\section{MATERIA I METODY BADAWCZE}

Badania wykorzystane na potrzeby niniejszego artykułu przeprowadzono w latach 2018-2020 wśród osób, do których kontakt pozyskano za pomocą metody snowball sampling. W pierwszym etapie $\mathrm{w}$ wywiadach przeprowadzonych online za pomocą komunikatora Skype wzięło udział 50 respondentów aktywnych na portalach społecznościowych (przede wszystkim na Facebooku). Były to osoby, które na podstawie roku

Tabela 1. Profil respondentów $(\mathrm{N}=409)$

\begin{tabular}{|c|c|c|c|}
\hline Zmienna & Kategoria & Liczba osób & Procent \\
\hline \multirow{2}{*}{ Płeć } & mężczyźni & 181 & 44 \\
\hline & kobiety & 228 & 56 \\
\hline \multirow{3}{*}{ Wiek } & $28-30$ & 205 & 50 \\
\hline & $30-35$ & 188 & 46 \\
\hline & $36-40$ & 16 & 4 \\
\hline \multirow{4}{*}{ Wykształcenie } & podstawowe & 0 & 0 \\
\hline & zawodowe & 21 & 5 \\
\hline & średnie & 15 & 4 \\
\hline & wyższe & 373 & 91 \\
\hline \multirow{5}{*}{ Miejsce zamieszkania } & miasto powyżej 500 tys. mieszkańców & 182 & 45 \\
\hline & miasto do 500 tys. mieszkańców & 128 & 31 \\
\hline & miasto do 100 tys. mieszkańców & 49 & 12 \\
\hline & miasto do 20 tys. mieszkańców & 14 & 3 \\
\hline & wieś & 36 & 9 \\
\hline \multirow{5}{*}{ Profil społeczno-zawodowy } & pracownik sektora publicznego & 97 & 24 \\
\hline & osoba wykonująca wolny zawód & 41 & 10 \\
\hline & pracownik sfery budżetowej & 108 & 26 \\
\hline & osoba samozatrudniona (własna działalność) & 163 & 40 \\
\hline & emeryt/rencista & 0 & 0 \\
\hline
\end{tabular}

Źródło: badania własne. 
Tabela 2. Kierunki podróżowania wskazane przez respondentów $(\mathrm{N}=409)$

\begin{tabular}{|l|c|}
\hline \multicolumn{1}{|c|}{ Kierunki podróży } & Wskazania podróży (\%) \\
\hline Chorwacja, Czechy, Słowacja & $37-43$ \\
\hline Węgry, Włochy & $26-31$ \\
\hline Austria, Czarnogóra, Niemcy, Polska, Rumunia, Ukraina & $20-25$ \\
\hline Bośnia i Hercegowina, Francja, Hiszpania, Norwegia, Serbia, Słowenia & $15-19$ \\
\hline Albania, Belgia, Bułgaria, Dania, Estonia, Gruzja, Holandia, Szwecja & $10-14$ \\
\hline $\begin{array}{l}\text { Białoruś, Chiny, Finlandia, Grecja, Islandia, Izrael, Litwa, Łotwa, Macedonia, Maroko, Mołdawia, } \\
\text { Mongolia, Palestyna, Portugalia, Rosja, Szwajcaria, Turcja, Wielka Brytania }\end{array}$ & $5-9$ \\
\hline $\begin{array}{l}\text { Armenia, Azerbejdżan, Brazylia, Egipt, Filipiny, Indie, Iran, Japonia, Jersey, Jordania, Kanada, } \\
\text { Kazachstan, Kirgistan, Korea Południowa, Kosowo, Kurdystan, Malezja, Malta, Monaco, Singapur, } \\
\text { Tadżykistan, Tajlandia, Tunezja, USA, Uzbekistan, Wietnam, Zjednoczone Emiraty Arabskie }\end{array}$ & $2-4$ \\
\hline
\end{tabular}

Źródło: badania własne.

urodzenia można uznać za należące do pokolenia milenialsów i które deklarowały, że są backpackerami. Następnie od tych respondentów uzyskano informacje o personaliach kolejnych osób spełniających przyjęte przez autorów kryteria. W efekcie w badaniu wzięło udział 409 ankietowanych, którzy są aktywnymi backpackerami i przynajmniej od pięciu lat uprawiają ten typ turystyki. Wszyscy respondenci byli w grupie wiekowej między 28. a 40. rokiem życia, a liczba kobiet przewyższyła liczbę mężczyzn. Zdecydowana większość respondentów posiadała wykształcenie wyższe. Najczęściej byli oni zatrudnieni na pełen etat $\mathrm{w}$ sektorze publicznym lub prywatnym. Żaden z ankietowanych nie zadeklarował, że jest bezrobotny (tab. 1 i 2).

Podczas przeprowadzania niniejszego badania posłużono się kwestionariuszem wywiadu (pytania otwarte). Pytania, które zadano respondentom, były skoncentrowane wokół pojęć związanych z ryzykiem $\mathrm{w}$ backpackingu. Skupiono się na empirii respondentów, mając na celu zrozumienie ich doświadczeń i przeżyć.

Wywiady zostały zapisane cyfrowo, a następnie transkrybowane w Microsoft Wordzie i przesłane do programu NVivo 11 Pro w celu stworzenia kluczy kodowych. Zakodowanie danych pozwoliło na przeprowadzenie analizy frekwencyjnej udzielonych odpowiedzi i wyłonienie $z$ nich różnych wątków problemowych o strukturze nadrzędnej i podrzędnej. Kody z kolei zostały przypisane bardziej znaczącym kategoriom, których utworzono pięć.

\section{WYNIKI}

Analiza odpowiedzi, które uzyskano podczas badania, pozwala wyodrębnić pięć zakodowanych kategorii ryzyka w backpackingu. Pierwsza zawiera się w postawie backpackerskiej i - zdaniem respondentów - jest szczególnie charakterystyczna dla tego typu podróży. Druga kategoria wpisana jest $\mathrm{w}$ poszukiwanie autonomii i niezależności. Trzecia wynika z zachowań adaptacyjnych, związanych z rachunkiem zysków i strat. Tę kategorię można nazwać kalkulacją selektywną. Czwarta, określana jako poszukiwanie wrażeń, związana jest z emocjonalnymi potrzebami backpackerów i ich pędem do przeżywania niezwykłych przygód. Ostatnia kategoria - uwarunkowania zewnętrzne (najrzadziej wskazywane) - wiąże ryzyko z warunkami klimatycznymi, geograficznymi, przyrodniczymi czy środowiskowymi w wybranych destynacjach.

\subsection{KATEGORIA 1: \\ BACKPACKERSKIE POSTAWY WOBEC PODRÓŻY}

Tematy łączące się z tą kategorią nawiązują do obszarów bezpośrednio wpisanych w sytuację bycia w drodze, takich jak: styl i cel podróży, zakwaterowanie, transport, podejmowana aktywność, odwiedzanie miejsc turystycznych lub niepopularnych, relacje z rdzennymi mieszkańcami. W wielu odpowiedziach respondentów (78\% wskazań) była mowa o zarysowującej się podczas ich podróży więzi z miejscem docelowym. Choć tego typu wyprawy są naznaczone ryzykiem, pozwalają spełniać backpackerom marzenia, osiągać cele, zdobywać doświadczenia, o czym świadczą ich następujące wypowiedzi:

- „W backpackingu tak naprawdę ryzyko występuje na każdym kroku, od dojazdu na miejsce po noclegi, transport, wyżywienie, spotkania innych itp. To duże przedsięwzięcie i trzeba liczyć tylko na siebie" ${ }^{\prime \prime}$.

-, „W backpackingu ryzykiem jest wszystko. Nigdy nie wiesz, do kogo wsiadasz, dokąd dojedziesz, gdzie będziesz spać, ale w tym jest właśnie to najbardziej pociągające i fascynujące".

- „Ryzykiem w backpackingu jest ufność wobec obcych. Rozpoczynając podróż, wsiadamy do auta z całkowicie obcą osoba, zdając się poniekąd na jej łaskę. Dalej odwiedzanie miejsc o mieszanej opinii, 
niepopularnych, gdzie nikt o zdrowych zmysłach by nie zajrzał. Ale my musimy, bo backpacker musi podejmować ryzyko, ponieważ efekty podjęte tego niebezpieczeństwa są totalnie tego warte".

- „Backpacking sam w sobie jest ryzykiem, gdy gnany marzeniami, wkraczasz na teren obcych - odkrywasz nieznane dotąd miejsca, poznajesz obcych sobie ludzi, wchodzisz w ich kulturę i życie, robisz coś, co powszechnie jest postrzegane jako coś potencjalnie niebezpieczne, mogące przysporzyć kłopotów, a to po prostu robienie czegoś, na co innym brak odwagi".

Ryzyko polega na porzuceniu własnej strefy komfortu, bezpieczeństwa i stabilizacji. Backpacker staje się wówczas odpowiedzialny sam przed sobą za wybory, których dokonuje. One stanowią integralną część jego tożsamości i są nieodłącznym elementem tego typu turystyki, która jak twierdzą respondenci, wymaga nieustannego wprowadzania zmian:

- „Podjęcie ryzyka daje nam, backpackerom, gwarancję, że zrealizujemy marzenia i pasje bez względu na konsekwencje osobiste".

- „Ryzykujemy ciągle. Wybieramy nocleg, na który nie pozwoliłby sobie człowiek mieszkający w jednym miejscu, jemy coś, czego nie dotknąłby przeciętny turysta itd.".

- „W backpackingu zazwyczaj ryzyko jest związane $z$ niepewnością. Nie jest to targanie się na swoje życie i za wszelką cenę dotarcie do wyznaczonego celu, a raczej, oczywiście w pewnym sensie, porywanie się z motyką na słońce i próba podejmowania niemożliwego".

- „W backpackingu podejmujemy wiele ryzyk, jest to forma wykraczania poza granicę komfortu".

Ryzyko w tej kategorii można zatem zdefiniować jako zakres działań, których podejmowanie wynika z faktu, że podróż jest związana z ruchem i interakcją. To wektor zmian wynikających z wyjścia ze strefy pozorów, w której funkcjonuje backpacker na co dzień, i zetknięcia się z innym miejscem i obcą kulturą.

\subsection{KATEGORIA 2: AUTONOMIA I NIEZALEŻNOŚĆ}

Druga kategoria obejmuje tematy związane z wolnością i niezależnością: wyzwolenie, ucieczka, samostanowienie, brak ograniczeń (59\% wskazań). Ryzyko w tej kategorii należy rozumieć jako potrzebę odejścia od wszystkiego, co jest zbyt powszednie, zwyczajne, codzienne, od norm i porządku społecznego, w których egzystuje się na co dzień. To szansa na odkrycie szerokiego wachlarza doznań, doświadczenie emocji, przeniknięcie do nowych miejsc i kontakt z nieznajomymi. Ten specyficzny akt nieskrępowanych działań, wolnych od społecznej odpowiedzialności, jest namiastką powrotu do okresu adolescencji, gdy wszystko wydawało się możliwe, o czym respondenci wspominali w swoich wypowiedziach:

- „Ryzyko w wielu przypadkach to tylko myśl w głowie człowieka, a nie prawdziwa sytuacja zagrażająca życiu. Backpacker widzi to inaczej, ryzyko pozwala na przeżywanie wolności, adrenaliny i niezależności".

- „To nowe doświadczenia, ucieczka, szaleństwo, oderwanie od codzienności. Ryzyko w backpackingu prawie zawsze wiąże się z nieoczekiwanymi sytuacjami, których nie doświadczamy na co dzień w tradycyjnym życiu".

- „Dla wielu ryzyko łączy się z niepewnością przed tym, co czeka nas w przyszłości. A ja uważam, że ryzyko jest wtedy, gdy możesz coś stracić. W backpackingu prawie zawsze zyskujesz. Owszem możesz stracić, ale tak samo w codziennym, zwykłym życiu. Wydaje mi się, że ryzyko podróżowania jako backpacker jest niewielkie. A nawet np. ryzyko nudnego życia jest zerowe, jeśli podróżujesz jako backpacker. Wszystko zależy od tego, co najbardziej cenisz w życiu. Jeżeli cenisz np. przewidywalność i poukładane życie, to backpacking nie jest dla ciebie".

- „Moim zdaniem ryzyko to zrobienie czegoś bez konieczności zastanawiania się, jaki będzie tego efekt. To spontaniczność. Żadnych norm. Po prostu całkowite wyzwolenie. Nigdy nie czuję się tak wolny, jak w chwili, gdy staję do wygranej z ryzykiem. Jestem wtedy jak dziecko zafascynowane pokonaniem smoka".

Podejmowanie ryzyka podczas podróży sprawia, że życie zdaje się prostsze, swobodniejsze, autentyczne. W tym stwierdzeniu kryje się pewien paradoks. Ryzyko bowiem jawi się tu jako nośnik doświadczeń nieskomplikowanych czy trywialnych. Podczas podróży jest ono jednak - jak stwierdziła jedna z respondentek - „naznaczone bieżącą kalkulacją możliwości sytuacji awaryjnych, które łatwo przyswajamy, bo one bawiąc, uczą". Trzeba naprawdę mieć różne umiejętności, by poradzić sobie w trudnych sytuacjach:

Jeżeli człowiek jest rozsądny i wie, jak się zachować w różnych sytuacjach, a tę wiedzę zdobywa z podróży na podróż, to sytuacje ryzykowne są coraz mniej trudne, mniej skomplikowane, można im stawić czoła i to jest niezwykłe. Właściwie to wtedy trud jest minimalny, taki sam jak, gdy człowiek chodzi po własnym miejscu zamieszkania.

\subsection{KATEGORIA 3: KALKULACJA SELEKTYWNA}

W odniesieniu do trzeciej kategorii respondenci w swoich wypowiedziach (44\% wskazań) wiązali ryzyko z racjonalizacją zysków i strat. Tematami pomocniczymi stały się: użyteczność, sposoby minimalizacji zagrożenia, koszty. Ryzyko jest oceniane pozytywnie, gdy 
stanowi szansę, a więc wynika z podjęcia wyzwania realizowanego konsekwentnie i z rozwagą:

- „To są takie sytuacje, które mogą w jakikolwiek sposób zmienić nasz cel podróży, nasze spotkania i sytuacje. Trzeba mieć odwagę do rozsądnych kalkulacji, co możemy zyskać, i tą drogą iść".

- „Ryzyko w backpackingu nie jest niebezpieczeństwem, jest bardziej związane z właściwym wyborem tych lepszych sposobów realizacji podróży”.

- „Przemyślane decyzje, które pomimo trudnych sytuacji, przynoszą nam korzyść i satysfakcję".

- „Trudność, którą w realizowaniu celu musimy przezwyciężyć, by zyskać".

W każdym innym przypadku ryzyko będzie postrzegane negatywnie, jako doświadczenie przynoszące straty. W ocenie respondentów niemożliwe jest bowiem, by współistniał jakiś konglomerat wartości zmiennych, który byłby niezależny od sytuacji:

- „Ryzyko wiąże się ze skalkulowanym, przemyślanym działaniem, biorącym pod uwagę, że coś może pójść nie tak".

- „Trzeba poważnie zdawać sobie sprawę, że wszystko może mieć negatywne, jak i pozytywne skutki, w zależności od sytuacji, w jakiej się znajdujemy. Owszem, mogą zaistnieć konsekwencje, których nie możemy przewidzieć. Ale w większości ignorowanie niebezpieczeństw wiąże się z utratą czegoś: zdrowia, życia lub kogoś, czegoś”.

- „Ryzyko kojarzy mi się z takim głupim zachowaniem, przez które istnieje możliwość utraty czegoś, co jest dla mnie ważne (zdrowie, życie, pieniądze, wartościowe przedmioty) itp.".

- „Nieodpowiedzialne działanie, którego konsekwencje mogą być bardzo poważne".

Podejmowanie ryzyka - zdaniem tej grupy respondentów - jest zatem działaniem, mającym na celu osiągnięcie oczekiwanych efektów. Oznacza ono wybór związany z dynamicznie zmieniającymi się warunkami podróżowania. Ryzyko nie łączy się zaś ze świadomym, czy nawet bezmyślnym narażaniem się na sytuacje, w których konieczne będzie podejmowanie pochopnych decyzji, niemniej jednak w społeczności backpackerskiej zdarza się również, że prowadzone są działania ryzykowne (brawurowe), o czym respondenci wspominali w swoich wypowiedziach:

- „Są backpackerzy, którzy ryzykują wbrew zdrowemu rozsądkowi. Wedle mnie to popis. Odwaga to po prostu bycie rozważnym".

- „Jeśli ktoś uważa, że ryzyko w backpackingu jest podniecające, to nic nie rozumie. Nie chodzi w tym o chojractwo. Martwy nie poznasz świata. Nie warto skakać do basenu, w którym nie ma wody".

- „Głupota i buractwo. Tak to rozumiem”.

- „Ryzyko nie jest brawura. Gdyby tak było, płacilibyśmy za tę głupotę najwyższą cenę".

\subsection{KATEGORIA 4: POSZUKIWANIE WRAŻEŃ}

Ryzyko w wypowiedziach respondentów (41\% wskazań) zostało przedstawione również jako stymulacja bodźcami o dużym ładunku emocjonalnym. W tej kategorii ważnymi zagadnieniami są: adrenalina, przygoda, doznania, eksploracja, bodźce. W analizowanych wypowiedziach ankietowani jawią się jako osoby poszukujące silnych wrażeń, zewnętrznej ekscytacji, by - zgodnie z terminologią Zuckermana (1994) - znaleźć dla siebie optymalny poziom stymulacji i pobudzenia. Bez tego życie wydaje im się stereotypowe i nudne. Z tej przyczyny podejmują działania ryzykowne, z jednej strony ujawniające potrzebę doświadczania inności i przekraczania granic, z drugiej zaś - przeżywania przygód i odczuwania różnorodnych, intensywnych emocji. Zastanawiający jest jedynie fakt, że opisując swoją aktywność, skupiają się wyłącznie na ryzyku o charakterze fizycznym, a zagrożenia związane ze sferą moralna, medyczna, społeczną czy finansową pomijają milczeniem.

Założenie Fuchs (2013), iż backpackerzy stanowią odrębną kategorię podróżnych, którzy pod względem zachowań związanych z ryzykiem podczas podróży różnią się od zinstytucjonalizowanych turystów masowych, jest błędne. Backpackerzy nie są bowiem społecznością homogeniczną pod względem postrzegania ryzyka (Reichel, Fuchs, Uriely, 2007). Z tego powodu konieczne wydaje się przeprowadzenie badań mających na celu wyjaśnienie złożoności ich postaw i zachowań związanych z ryzykiem. Przy wypełnianiu tej luki w literaturze pomocna mogłaby być opracowana przez Zuckermana skala poszukiwania doznań (Sensation Seeking Scale). Zestawiając z nią odpowiedzi respondentów, można przede wszystkim zauważyć, że dwa z czterech zapisanych przez Zuckermana czynników stymulujących pokrywają się z uwarunkowaniami wskazanymi przez ankietowanych. Pierwszy - experience seeking - to odrzucenie konformistycznego stylu życia i wyruszenie w podróż w celu poszukiwania nowych doświadczeń, gdyż jak zauważali ankietowani:

- „Ryzyko jest próbą czegoś nowego, nieznanego, nowym doświadczeniem, przełamywaniem barier".

- „Ryzyko wiąże się z podróżą do trudno dostępnych miejsc, do których inni turyści nie dochodza, i my o nich nie wiemy zbyt wiele, ale dzięki temu poznajemy obce osoby i ich kulturę".

- „To robienie czegoś, co jest powszechnie postrzegane jako coś potencjalnie niebezpieczne, mogące przysporzyć kłopotów; innym brak takiej odwagi, a my idziemy".

- „Eksploracja, pokonywanie swojej granicy i słabości”. Drugi czynnik - boredom susceptibility - opiera się na niechęci do rutyny, unikaniu obowiązków, porzuceniu nawyków dnia codziennego oraz braku zgody na zastaną rzeczywistość: 
- „Ryzyko jest przypływem energii, gdy istnieje zagrożenie, czasem niepewność, ale wtedy wiem, że wyrwałem się ze swojej klatki, przeżywam coś, czego nie przeżyłbym w swoim domu".

- „Ryzyko nauczyło mnie jak mam przełamywać swoje bariery i nie gubić się w codziennym życiu”.

- „Ryzyko jest dla mnie wyzwoleniem od nudy, pokonaniem swoich słabości, lenistwa".

- „Osiąganiem wyższych celów”.

W niewielu wypowiedziach pojawiło się utożsamienie ryzyka z zabawą (5,8\% wskazań):

- „Adrenalina, dobra zabawa, emocje, ale w granicach rozsądnych".

- „Przygoda i wspomnienia nie do zapomnienia, a nie do leczenia! :)".

- „Jest ryzyko, jest zabawa”.

- „Radość, śmiech, zabawa i przygoda”.

Trudno dopatrywać się w tych opiniach bezpośredniego odwzorowania trzeciego czynnika Zuckermana - rozluźnienia hamulców społecznych (Disinhibition). Raczej chodzi o lekki i przyjemny sposób spędzania czasu w podróży, bez utraty kontroli nad własnym działaniem i ponoszeniem negatywnych skutków braku zahamowań. Badania pokazują, że postrzeganie ryzyka, opisane przez respondentów, nie jest równoznaczne z jego podejmowaniem oraz że ryzyka i poszukiwania wrażeń nie można uznać za tożsame pojęcia.

\subsection{KATEGORIA 5: UWARUNKOWANIA ZEWNĘTRZNE}

W piątej kategorii ryzyko zostało powiązane z warunkami klimatycznymi, geograficznymi, przyrodniczymi oraz środowiskowymi. Należy zwrócić uwagę, że ten ostatni zbiór miał wśród respondentów najmniejszą liczbę wskazań (wzmiankowało o nim zaledwie 18\% badanych). Ta ostatnia kategoria obejmuje tylko trzy zagadnienia: klimat, politykę i środowisko. Respondenci, charakteryzując swoje podróże, zwracali uwagę na możliwość utraty zdrowia, a nawet życia, lub też odniesienia obrażeń fizycznych w wyniku różnych nieprzewidzianych okoliczności, szczególnie związanych z atakiem innych osób lub zwierząt:

- „Ryzyko to możliwość zajścia nieprzyjemnych i niebezpiecznych zdarzeń; sytuacje zagrożenia, w których serce bije szybciej, typu napaść, kradzież, dzikie zwierzęta".

- „Obawa przed czyhającymi niebezpieczeństwami na każdym kroku i bezradność w przypadku natknięcie się na jedno z nich".

- „Odkrywanie nieznanych miejsc, czasem dzikich i nieprzewidywalnych, nie wiadomo, na jakich ludzi się tam trafi".
- „W backpackingu ryzyko jest związane ze zdawaniem się na nieznajome osoby. Można trafić na przestępców różnej maści".

Inny rodzaj poczucia zagrożenia, jakie respondenci wiązali z ryzykiem, łączy się z niestabilnością polityczną lub klimatyczną w odwiedzanym kraju:

- „Ryzyko to podróżowanie do krajów, w których sytuacja polityczna lub klimatyczna zagraża życiu i bezpieczeństwu".

- „Ryzyko jest wszędzie, wszystko teraz jest niebezpieczne. Wojna w Syrii, konflikt w Górskim Karabachu, w Afryce, na Bliskim Wschodzie, podróżujesz do krajów i nie wiesz, czy sytuacja polityczna nie grozi ci niewróceniem z podróży".

- „Sytuacja polityczna i problemy z klimatem, powodzie, huragany, pożary są niebezpieczeństwem i narażaniem się na ryzyko. Ale w backpackingu ryzyko nawet takie może prowadzić do osiągania czegoś lub zdobycia (nie chodzi o materialne dobro) przy pewnym tymczasowym poświęceniu czegos'".

- „Niebezpieczeństwo nie jest zależne ode mnie, to coś, czegoniemożna uniknąć.Zmiany politycznew krajach, gdzie jedziemy, jakieś kataklizmy to jest [sic!]. Nieważne, jaki tryb życia prowadzisz. Potencjalnie i w domu może stanowić to dla ciebie zagrożenie. Więc strach trzeba przezwyciężyć i jechać ze świadomościa, że nie zawsze jesteśmy bezpieczni i nie zawsze będziemy się znajdować w komfortowych sytuacjach".

Zdaniem autorów niniejszego artykułu powodem tak niewielkiego zakresu wskazania ryzyka wynikającego z warunków zewnętrznych jest niewątpliwie główny nurt zainteresowań backpackerów, w trakcie podróży skupiają się oni bowiem przede wszystkim na zdobywaniu doświadczeń, odkrywaniu nowości, odczuwaniu zmian. Ryzyko staje się dla nich motywacją do podróżowania, a więc jest ono czymś pozytywnym. Zapewne z tego wynika fakt, że backpackerzy w większym stopniu niż inni turyści aprobują zdarzenia ryzykowne, postrzegając je jako korzystne wrażenia z podróży. Hunter-Jones, Jeffs i Fischbacher-Smith (2007) pisali, że odczuwanie ryzyka ma charakter mocno subiektywny - poziom tolerancji, powyżej którego staje się ono nie do zniesienia (zaczyna być postrzegane jako negatywne), nie jest jednakowy dla różnych grup turystów. Wydaje się, że w przypadku backpackerów ten próg jest bardzo wysoki, i zapewne z tego powodu w niewielkim stopniu przejmują się oni warunkami zewnętrznymi.

\section{DYSKUSJA}

W światowej literaturze przedmiotu podkreśla się, że ryzyko w backpackingu odnosi się do różnych sfer podróży. Ma związek m.in. z: samotnym przemierzaniem 
przez backpackerów różnych zakątków świata; nocowaniem i stołowaniem się w miejscach niespełniających podstawowych wymogów sanitarnych i prawnych; ignorancją zasad BHP oraz brakiem zahamowań (Elsrud, 2001; Issahaku, 2015; Jabłonkowska, 2015, 2017a, 2017b; Watcharapong i in., 2010). Nie wszystkie wymienione obszary zostały opisane w niniejszym badaniu. Respondenci przede wszystkim wiązali ryzyko z sytuacjami wpisanymi w ten typ podróżowania. Dodatkowo niejako synonimami ryzyka stały się: wyzwolenie, samostanowienie, użyteczność, koszty, adrenalina, przygoda, eksploracja. Jednakże w opinii respondentów granice dążenia do osiągnięcia tych wartości wyznaczają rozwaga i podstawowe zasady bezpieczeństwa - istotna staje się kalkulacja zysków i strat.

W deklaracjach respondentów nie zostały zaznaczone te rodzaje ryzyka, które - jak się wydaje - w sposób oczywisty wynikają z uprawiania backpackingu ${ }^{2}$. Nikt $\mathrm{z}$ respondentów $(\mathrm{N}=409)$ nie wspomniał o ryzyku medycznym - związanym z utratą zdrowia w wyniku rozwoju infekcji podczas podróży, choć wiadomo, że istnieje zależność między podróżami a większą zachorowalnością na choroby zakaźne. Nikt też nie wspominał o ryzyku chorób psychicznych (tj. lęków, depresji, uzależnień), które mogą wynikać z trudnych doświadczeń, a przecież w światowej literaturze wskazuje się, że stres związany z zagrożeniem wywiera negatywny wpływ na stan zdrowia psychicznego backpackerów. Potwierdzają to choćby wyniki badań Yody, Yokoyamy, Suzuki i Hirao (2017), którzy wskazali związek między doświadczeniem powodzi w Tajlandii w $2011 \mathrm{r}$. a chorobami psychicznymi u turystów znajdujących się wówczas w okolicach Bangkoku. Wcześniej podobne badania wśród backpackerów przeprowadzili Piyaphanee, Olanwijitwong, Kusolsuk i Silachamroon 2012). Z kolei Stewart i Leggat (1998) opisali aspekt zaburzeń psychicznych po zetknięciu się z inną niż własna, egzotyczną kulturą. Ich zdaniem - pomimo że backpackerzy w założeniu uznają kontakt $\mathrm{z}$ inną kulturą za doświadczenie korzystne, służące m.in. lepszemu rozumieniu świata, budowaniu dobrych relacji międzykulturowych, kształtowaniu osobowości czy choćby ucieczce od nudy wpisanej w rutynę dnia codziennego - szok i stres wynikające z różnic kulturowych mogą stanowić zagrożenie dla zdrowia psychicznego backpackerów i stać się przyczyną m.in. depresji, lęków, bezsenności, uzależnień, wrogości czy agresji.

Respondenci nie opisywali również sytuacji, które ukazałyby ich gotowość do podejmowania niebezpiecznej aktywności sportowej czy rekreacyjnej, nawiązywania ryzykownych relacji z lokalną społecznościa, nieprzestrzegania prawa. Respondenci nie przyznawali się również do takich zachowań, jak zażywanie narkotyków, nadużywanie alkoholu czy przypadkowe stosunki seksualne, pomimo że zagadnienia te są opisywane w literaturze przedmiotu. Przykładowo Fischer i in. (2010) badali, czy seks jest kluczowym czynnikiem sprawiającym, że kobiety decydują się na backpacking, oraz głównym wyznacznikiem zadowolenia z takiej podróży. Naukowcy wskazywali, że wybór destynacji, towarzyszy podróży, miejsca noclegu i wypoczynku dla respondentek biorących udział w badaniu okazał się istotny, ponieważ był motywowany tworzeniem warunków umożliwiających odbycie nieformalnego stosunku płciowego (zob. Carr, Poria, 2010).

\section{WNIOSKI}

Zaprezentowane $\mathrm{w}$ niniejszym artykule badania nie tylko są wyzwaniem naukowym, lecz także - w epoce zglobalizowanego backpackingu - stanowią istotny kierunek w odniesieniu do rynku usług. Zebrany materiał empiryczny bowiem może stanowić cenne źródło informacji przydatnych przy tworzeniu produktów turystycznych, adresowanych do tego mało rozpoznanego w warunkach polskich segmentu rynku. Analizy przeprowadzone wśród respondentów z pokolenia milenialsów - generacji poszukującej niezależnego stylu podróżowania i nowatorskich koncepcji rozwoju - pozwalają spojrzeć na tę społeczność z innej perspektywy, przy uwzględnieniu jej waloryzującego podejścia do ryzyka. Uczestniczące w badaniu osoby z tego pokolenia przyporządkowały znaczenie ryzyka do różnych kategorii, których wspólnym mianownikiem stała się racjonalizacja doświadczeń. Respondenci wyruszają w backpackerskie podróże (ryzyko jest $\mathrm{w}$ ich przekonaniu powiązane z tym stylem podróżowania), przemieszczają się swobodnie bez sprecyzowanego planu mało uczęszczanymi trasami, wnikają w kulturę odwiedzanego kraju i nawiązują kontakty z jego mieszkańcami, kalkulując możliwości zysków i strat. Rezygnują z wygody na rzecz autentycznych przeżyć płynących z dokonania czegoś, pozyskania kompetencji, przezwyciężenia własnych słabości i pokonania barier. Niemniej jednak przy podejmowaniu ryzyka związanego z tymi potrzebami musi być spełniony jeden warunek - nieprzekraczanie granic bezpieczeństwa.

Przy tworzeniu nowych usług oferowanych backpackerom na rynku turystycznym i rekreacyjnym, należy uwzględnić takie rozwiązania, które realnie odwzorują w współczesny fenotyp backpackera i jego rozumienie ryzyka. Takie produkty już powstaja, choć wciąż jest ich mało i nie wypełniają luki w spełnianiu oczekiwań backpackerów. Przykładowo w Australii oferowane są atrakcje turystyczne umożliwiające podejmowanie „bezpiecznego" ryzyka. Są one reklamowane jako podróże przygodowe. Jest to próba odpowiedzi na potrzebę specyficznej aktywności, w której 
podejmowane są działania ryzykowne, ale bez realnego zagrożenia czy ponoszenia strat. Taka aktywność umożliwia backpackerom kreowanie się na doświadczonych podróżników oraz stworzenie poczucia przekraczania granic, mimo iż opiera się ono jedynie na iluzoryczności. Również w Nowej Zelandii, popularnym kierunku podróży backpackerów, są miejsca, gdzie można przeżyć ekscytującą przygodę. W przypadku tego typu atrakcji kluczową kwestią nie jest realne zagrożenie, a jedynie aktywność wywołująca dreszczyk emocji.

\section{PRZYPISY}

\begin{abstract}
${ }^{1}$ We wszystkich zacytowanych $\mathrm{w}$ artykule wypowiedziach repsondentów zachowano pisownię oryginalną.

${ }^{2}$ Fuchs (2013) wskazuje, że turystyka charakteryzuje się specyficznymi cechami, takimi jak: niematerialność, nierozłączność, zmienność i nietrwałość, a na produkt turystyczny wpływ mają szczególne czynniki, takie jak: zła pogoda, relacje międzyludzkie, strajkujący personel lotniska, terror, przestępczość, niepokoje polityczne, choroby i klęski żywiołowe. Czynniki te często podnoszą poziom dostrzeganego przez turystów ryzyka, co zwykło się określać mianem "ryzyka podróży” lub „celu podróży”. Zostały określone 43 czynniki ryzyka związane z turystyka, od poważnych zdarzeń, takich jak klęski żywiołowe, po trywialne sprawy, jak np. uczestniczenie w wycieczce. Tsaur, Tzeng i Wang (1997) opisali rodzaje ryzyka związane z chorobami, przestępczościa, wypadkami, higieną, niebezpieczeństwem, wynikające z podróżowania różnymi środkami transportu, z barier kulturowych oraz niepewności co do przepisów prawa w miejscu docelowym. Sönmez i Graefe (1998) wyszczególnili ryzyko związane z kwestiami finansowymi, funkcjonalnymi oraz fizyczne, psychologiczne, społeczne, satysfakcji, czasu, zdrowia, niestabilności politycznej i terroryzmu.
\end{abstract}

\section{BIBLIOGRAFIA}

Baran, M., Kłos, M. (2014). Pokolenie Y - prawdy i mity w kontekście zarządzania pokoleniami. Marketing i Rynek, 5, 923-929.

Bellis, M.A., Hughes, K., Dillon, P., Copeland, J., Gates, P. (2007). Effects of backpacking holidays in Australia on alcohol, tobacco and drug use of UK residents. BMC Public Health, 7 (1), 1-10. DOI: https://doi.org/10.1186/1471-2458-7-1

Carr, N., Poria, Y. (2010). Sex and the sexual during peoples leisure and tourism experiences. Newcastle: Cambridge Scholars Publishing.

Desforges, L. (2000). Traveling the world. Identity and travel biography. Annals of Tourism Research, 27 (4), 926-945. DOI: https://doi.org/10.1016/S0160-7383(99)00125-5

Elsrud, T. (2001). Risk creation in traveling. Backpacker adventure narration. Annals of Tourism Research, 28 (3), 597-617. DOI: https://doi.org/10.1016/S0160-7383(00)00061-X

Falconer, E. (2011). Risk, excitement and emotional conflict in women's travel narratives. Manchester: Metropolitan University.

Fazlagić, J.A. (2008). Charakterystyka pokolenia Y. E-mentor, 3 (25), 13-16.
Fischer, J., Rostami, S., Peet, A., Dean, J., Debattista, J., Allen, K. (2010). Sex, drugs and backpacking: Study report. Queensland: Alcohol Education \& Rehabilitation Foundation Ltd.

Fuchs, G. (2013). Low versus high sensation-seeking tourists: A study of backpackers' experience risk perception. International Journal of Tourism Research, 15, 81-92. DOI: https:// doi.org/10.1002/jtr.878

Hunter-Jones, P., Jeffs, A., Fischbacher-Smith, D. (2007). Backpacking your way into crisis: An exploratory study into perceived risk and tourist behavior amongst young people. Journal of Travel \& Tourism Marketing, 23 (2-4), 237-247. DOI: https:// doi.org/10.1300/J073v23n02_18

Issahaku, A. (2015). Backpackers' risk perceptions and risk reduction strategies in Ghana. Tourism Management, 49, 99-108. DOI: https://doi.org/10.1016/j.tourman.2015.02.016

Iyer, R., Reisenwitz, T.H. (2009). Differences in generation $X$ and generation Y: Implications for the organization and marketers. Marketing Management Journal, 19 (2), 91-103.

Jabłonkowska, J.B. (2015). Risk-taking factors in backpacker tourism. Zeszyty Naukowe Wyższej Szkoty Humanitas. Pedagogika, 11, 119-127.

Jabłonkowska, J.B. (2017a). Backpackerzy polscy a zagraniczni. Wieloaspektowe studium porównawcze. Wrocław: AWF we Wrocławiu.

Jabłonkowska, J.B. (2017b). Alkoholowe, narkotykowe i seksualne „rozhamowanie” backpackerów w świetle międzynarodowych badań porównawczych. Folia Turistica, 43, 153-166. DOI: https://doi.org/10.5604/01.3001.0010.7888

Kotler, P., Wong, V., Saunders, J., Armstrong, G. (2005). Principles of marketing. New Jersey: Prentice Hall FT.

Kowalczyk-Anioł, J. (2012). Tourism trends among generation $\mathrm{Y}$ in Poland. Turyzm/Tourism, 22 (2), 15-20. DOI: https://doi. org/10.2478/v10106-012-0007-y

Kozak, M., Crotts, J.C., Law, R. (2007). The impact of the perception of risk on international travellers. International Journal of Tourism Research, 9 (4), 233-242. DOI: https://doi.org/10.1002/jtr.607

Kubacka-Jasiecka, D., Passowicz, P. (2014). Dorastanie we współczesności. Postawy, wartości i doświadczanie czasu a kryzysy rozwoju pokolenia po transformacji. Czasopismo Psychologiczne - Psychological Journal, 20 (2), 171-182.

Leggat, P.A., Shaw, M.T. (2003). Travel health advice for backpackers. Journal of Travel Medicine, 10 (6), 340-345. DOI: https:// doi.org/10.2310/7060.2003.9361

Lepp, A., Gibson, H. (2008). Sensation seeking and tourism: Tourist role, perception of risk and destination choice. Tourism Management, 29 (4), 740-750. DOI: https://doi.org/10.1016/j. tourman.2007.08.002

Lupton, D., Tulloch, B. (2002). Life would be pretty dull without risk: Voluntary risk-taking and its pleasure. Health, Risk and Society, 4 (2), 113-124. DOI: https://doi.org/10.1080/13698570220137015

Patyra, A., Dłużewska, A. (2015). Backpacking - historia, ramy, rozwój. Turystyka Kulturowa, 11, 40-54.

Pendergast, D. (2010). Getting to know the $\mathrm{Y}$ generation. W: P. Benckendorff, G. Moscardo, D. Pendergast (red.), Tourism and generation Y (s. 1-15). Cambridge: CABI, Oxfordshire. DOI: https://doi.org/10.1079/9781845936013.0001

Piyaphanee, W., Olanwijitwong, J., Kusolsuk, T., Silachamroon, U. (2012). Awareness, practices, and health problems of backpackers traveling during flooding in Thailand during 2011. Southeast Asian Journal Trop Med Public Health, 43 (5), 1193-1200.

Piyaphanee, W., Wattanagoon, Y., Silachamroon, U., Mansanguan, C., Wichianprasat, P., Walker, E. (2009). Knowledge, attitudes, and practices among foreign backpackers toward malaria risk in southeast Asia. Journal of Travel Medicine, 16 (2), 101-106. DOI: https://doi.org/10.1111/j.1708-8305.2008.00282.x 
Potasman, I., Beny, A., Seligmann, H. (2000). Neuropsychiatric problems in 2,500 long-term young travelers to the tropics. Journal Travel Medicine, 7 (1), 5-9. DOI: https://doi. org $/ 10.2310 / 7060.2000 .00002$

Reichel, A., Fuchs, G., Uriely, N. (2007). Perceived risk and the non-institutionalized tourist role: The case of Israeli student ex-backpackers. Journal of Travel Research, 46 (2), 217-226. DOI: https://doi.org/10.1177/0047287507299580

Ryan, C. (2003). Risk acceptance in adventure tourism: Paradox and context. W: J. Wilks, S. Page (red.), Managing Tourist Health and Safety in the New milennium (s. 55-65). Amsterdam: Elsevier Science. DOI: https://doi.org/10.1016/ B978-0-08-044000-2.50009-2

Santos, M.C., Veiga, C., Águas, P. (2016). Tourism services: Facing the challenge of new tourist profiles. Worldwide Hospitality and Tourism Themes, 8 (6), 654-669. DOI: https://doi.org/10.1108/ WHATT-09-2016-0048

Sönmez, S., Graefe, A. (1998). Determining future travel behavior from past travel experience and perceptions of risk and safety. Journal of Travel Research, 37 (4), 171-177. DOI: https:// doi.org/10.1177/004728759803700209

Stewart, L., Leggat, P.A. (1998). Culture shock and travelers. Journal of Travel Medicine, 5, 84-88. DOI: https://doi. org/10.1111/j.1708-8305.1998.tb00469.x

Tapscott, D. (2010). Cyfrowa dorosłość. Jak pokolenie sieci zmienia nasz świat. Tłumaczenie P. Cypryański. Warszawa: WAiP.
Tsaur, S., Tzeng, G., Wang, K. (1997). Evaluating tourist risks from fuzzy perspectives. Annals of Tourism Research, 24 (4), 796-812. DOI: https://doi.org/10.1016/S0160-7383(97)00059-5

Wantono, A., Mckercher, B., (2020) Backpacking and risk perception: The case of solo Asian women. Tourism Recreation Research, 45 (1), 19-29. DOI: https://doi.org/10.1080/0250828 1.2019.1636180

Watcharapong, P., Prapimporn, S., Weerapong, P., Piyada, U., Pongdej, W., Maneerat, B., Thitiya, P., Terapong, T. (2010). Rabies exposure risk among foreign backpackers in Southeast Asia. The American Journal of Tropical Medicine and Hygiene, 82 (6), 1168-1171. DOI: https://doi.org/10.4269/ ajtmh.2010.09-0699

Yoda, T., Yokoyama, K., Suzuki, H., Hirao, T. (2017). Relationship between long-term flooding and serious mental illness after the 2011 flood in Thailand. Disaster Medicine and Public Health Preparedness, 11 (3), 300-304. DOI: https://doi. org/10.1017/dmp.2016.148

Zuckerman, M. (1994). Behavioral expressions and biosocial bases of sensation seeking. New York: Cambridge University Press.

Artykuł wpłyną: 6 maja $2020 \mathrm{r}$ Zaakceptowano do druku: 6 listopada $2020 \mathrm{r}$. 